\title{
Reconnecting Forward: Nasjonal Samling's Apocalyptic Temporality as a Key to the Fascist Regime of Historicity
}

\author{
Fredrik Wilhelmsen \\ Faculty of Social Sciences, Nord University, Bodø, Norway \\ wilhelmsen.fredrik@gmail.com
}

\begin{abstract}
This article analyses the conception of history or 'regime of historicity' structuring the ideology of the Norwegian fascist party, Nasjonal Samling (1933-1945). It highlights the value of the theory of palingenetic ultranationalism to the understanding of fascist temporality generically and specifically. Generically, because the findings show how Nasjonal Samling's regime of historicity followed the same structure of revolution and eternity, decay and rebirth, as other fascist movements did. Specifically, because it also shows how Nasjonal Samling drew heavily on Norwegian national myths. The ideologues of ns recoded these myths, and integrated them into their own palingenetic, apocalyptic, and - after 1935 - antisemitic grand narratives. These crystallized in a triadic scheme, forming a fascist regime of historicity, structured around the myth of past greatness, followed by decadence, combined with a fantasy of a future revolutionary rebirth of the nation.
\end{abstract}

\section{Keywords}

Norway - Nasjonal Samling - fascism - temporality - regimes of historicity - generic fascism - national myths

Did fascism represent a revolutionary or a counter-revolutionary movement? According to American historical sociologist Dylan Riley, '[t]his question has 
always been the central dividing-line in the literature about it.' ${ }^{1}$ But could it be that there is something to be gained from phrasing the question slightly differently? Is not the question of whether or not fascism represents a revolutionary or a counter-revolutionary force more than a political question? Is it not also a question of narration, a question of how fascist ideologies place themselves in relation to the past, the present, and the future? And could it be that posing the question in these terms - revolutionary or counter-revolutionary? - is an attempt to establish if fascist movements look forward or backwards by implicitly using the opposition between the 'radical' left and the 'conservative' right as a yardstick when trying to identify the shape, direction and pace of time permeating fascist ideologies? As Juan Linz argued, fascism was a 'late-comer' onto the political scene. ${ }^{2}$ Since the ideological cards had already been dealt, fascist movements needed to occupy a residual political field. ${ }^{3}$ Perhaps fascist movements, then, had their own temporality, their own way of relating the past, the present and the future, not captured in this simple opposition?

Using the Norwegian party, Nasjonal Samling (1933-1945), as a case-study, the aim of this paper is to examine how a movement that can be labelled as 'fascist' in the generic sense has articulated the categories of the past, the present, and the future. In order to do this, I analyse speeches, articles and essays written by people in or associated with Nasjonal Samling, as well as their party program. What conception of history can we infer from this material? How did they articulate the categories of present, past and future in each case? Or, phrased differently: what 'regime of historicity' ${ }^{4}$ organised their thinking? And, finally, what kind of 'plots' provided the historical narratives of Nasjonal Samling with a sense of futurity and progress? The article draws on methodological and theoretical inspiration from two main traditions: cultural sociology and history of ideas. From the former, it builds upon the work of the 'strong program' of cultural sociology, associated with scholars such as Jeffrey C. Alexander and Philip Smith, and their ambition to understand the processes of 'meaning-making', and to reconstruct the cultural logic or 'culture structures'5

1 Dylan Riley, 'Enigmas of Fascism,' New Left Review, November 30, 2004, https:// newleftreview.org/issues/II3o/articles/dylan-riley-enigmas-of-fascism. Juan Linz, 'Political Space and Fascism as a Late-comer', in Who Were the Fascists: Social Roots of European Fascism, ed. Stein Ugelvik Larsen (Bergen: Universitetsforlaget, 1980), 153-189.

3 Mabel Berezin, 'Fascism,' in Encyclopedia of Sociology, ed. George Ritzer (London: Blackwell, 2005). Columbia University Press, 2016). 
behind utterances and cultural systems. From the latter, it applies François Hartog's notion of 'regimes of historicity', Reinhart Koselleck's analyses of historical changes in our collective experience of time, and Roger Griffin's ideal-type model of generic fascism and work on fascist temporalities.

Before delving into Nasjonal Samling's historical narratives, I provide an outline of the methodological and theoretical points of departure, starting with Alexander and Smith.

\section{A Cultural Sociological Approach to Political Ideas}

The inspiration that this present article draws from the cultural sociology of Alexander and Smith, derives from their focus on the processes of meaning-making, and their commitment to hermeneutical reconstruction and interpretation of 'the codes, narratives, and symbols that create the textured webs of social meaning'. ${ }^{6}$ Focusing on the 'culture structures' and 'domains of meaning' underpinning social behavior, Alexander and Smith treat the cultural 'foreground' of ideologies seriously, seeing them neither as window dressing or as a reflection of a 'false consciousness' in the Marxian sense, but as symbolic systems that provide 'meaning and motivation.'

As we will see below, this Geertzian inspired focus on the webs of meaning 8 provides a valuable approach to the study of Nasjonal Samling's ideology in general and to its narration of history in particular. A cultural sociological approach can help us recognise how a narrative form is not simply arbitrarily imposed on either the ideology or on pre-existing 'facts' about the course of history, but is constitutive and helps give them form. ${ }^{9}$ In the ideology of Nasjonal Samling, as we will see below, elements from the past were incorporated into a narrative logic, a 'plot' that created a sense of interconnectedness and meaningfulness in the light of a myth about the past ('the beginning'), a diagnosis of the present ('the middle'), and a prophecy about the future ('the end'). ${ }^{10}$ The

$6 \quad$ Alexander, The Meanings of Social Life, 13.

7 Ibid., 199; Smith, Why War?, 10-11.

8 See Clifford Geertz, The Interpretation of Cultures: Selected Essays (New York: Fontana Press, 1993).

$9 \quad$ Lois Presser, 'The Narratives of Offenders,' Theoretical Criminology 13, no. 2 (2009): 181; Lise Kjølsrød, Leisure as Source of Knowledge, Social Resilience and Public Commitment (London, New York: Palgrave Macmillan, 2018), 11.

Hayden White, Metahistory: The Historical Imagination in 19th-Century Europe (Baltimore: John Hopkins University Press, 1973); 'Historien som narrativitet,' in Fortiden i nåtiden: Nye veier i formidlingen av andre verdenskrigs historie, ed. Claudia Lenz og Trond Risto Nilssen

(Oslo: Universitetsforlaget, 2011). 
same historical 'facts' used by Nasjonal Samling, could, however, be integrated into a contrasting narrative logic, of which we will also see examples.

As I attempt to show in the following, a cultural sociological approach to fascism is compatible with Roger Griffin's highly influential ideal-type model of 'generic fascism'. Like Alexander and Smith, Griffin has taken a more 'cultural' approach to the study of society, ${ }^{11}$ and launched an understanding of fascism that focuses on the three mythic components that he considers to make up its 'minimum': ultra-nationalism, the myth of decadence, and the rebirth myth. ${ }^{12}$ Like Alexander and Smith, Griffin takes the cultural 'foreground' and speech acts seriously as testimony of an ideology rooted in passionately held beliefs and ideals inferable from primary sources, and on this premise he suggests that fascism is best defined as a revolutionary ('palingenetic') form of populist ultranationalism. ${ }^{13}$

While such an understanding of 'fascism' is widely used, it is still contested and divides opinion: Christopher Clark has for instance rejected the idea that it is possible to identify a 'generic "fascist" temporality',14 arguing that Italian Fascism and German Nazism each had their own 'distinctive' temporal orders. Yet, this article adopts - and hopefully further develops - the understanding of fascist temporalities that has not only been formulated and refined by Griffin, but also by scholars such as Fernando Esposito, Sven Reichardt, and Raul Carstocea. ${ }^{15}$ In his rejection of any 'generic "fascist" temporality', Clark argued that German Nazism represented 'a radical rejection of "history" and a flight into deep continuity with a remote past and a remote future.'16 While Clark certainly has a point when he identifies this anti-historicist character of Nazism, this current article enters into a dialogue with the research of Griffin, Esposito, Reichardt, and Carstocea, and argues that what Clark labels as a distinctive rejection of history, is rather the hybrid temporality characteristic of generic fascism - a hybrid temporality that combines a desire for future

Roger Griffin, 'The Primacy of Culture: The Current Growth (Or Manufacture) of Consensus within Fascist Studies,' Journal of Contemporary History 37, no. 1 (2002): 21-43. Roger Griffin, The Nature of Fascism (London: Routledge, 1991), 201; Jens Rydgren, The Oxford Handbook of the Radical Right (Oxford: Oxford University Press, 2018), 6. Griffin, The Nature of Fascism, xi. Christopher Clark, 'Time of the Nazis: Past and present in the Third Reich,' Geschichte und Gesellschaft, Sonderheft 25 (2015), 156.

See Journal of Modern European History's special issue on fascist temporalities:Journal of Modern European History 13, no. 1 (2015).

Clark, 'Time of the Nazis,' 185 . 
transcendence and revolution with a longing for roots and belonging which constitutes its own vision of the historical process and 'philosophy of history'.17

In order to analyse the temporal dimension of Nasjonal Samling's ideology, this present article also utilises François Hartog's notion of 'regimes of historicity', as it allows us to isolate how the relations between the past, the present, and the future are articulated. The key for comprehending the way someone 'temporalises' history, Hartog claims, is to be found in how s/he relates these three categories to one another. ${ }^{18}$ When confronted with a specific material, Hartog asks: which category is dominant in each case - the past, the present, or the future? And from this line of inquiry, he tries to derive a specific order of time. The heuristic value of utilising such a method in the study of a movement like Nasjonal Samling, is precisely that it can help us uncover how they situated themselves in the flow of time, thus making it easier to examine what kind of futural horizon - dystopian? optimistic? violent? apocalyptic? - is invoked by the movement. Utilising such a method, Hartog's key argument is similar to the one Reinhart Koselleck put forward in Futures Past: that until the French Revolution, the past was seen as informing the present. From 1789 and forwards, however, the present and the past were conceived in terms of the future. ${ }^{19}$ The question now becomes: how does a fascist movement like Nasjonal Samling fit into these notions of how time is experienced in modern societies?

\section{Nasjonal Samling: Binary Codes and Narratives of Palingenesis and Apocalypse}

When we delve into the party program and the speeches, articles and essays written by representatives of the Norwegian fascist party, Nasjonal Samling (hereby referred to as NS), we soon discover the value of studying it through the lens of Griffin's approach to fascism and Alexander and Smith's approach to cultural sociology. We are immediately confronted with an ideology that is constructed around binary codes and temporal narratives, the former - to paraphrase Alexander - deeply 'othering' and Manichaean (us/them, pure/

Fernando Esposito, Fascism, Aviation and Mythical Modernity (Basingstoke: Palgrave Macmillan, 2015), 289.

18 Hartog, Regimes of Historicity, xvi.

19 Stefan-Ludwig Hoffman, [book review of] 'François Hartog, Regimes of Historicity: Presentism and Experiences of Time,' The American Historical Review 121, no. 2 (2016): 535-536, https://doi.org/10.1093/ahr/121.2.535. 
impure), the latter 'heroic' and regenerative, shrouded in the rhetoric of apocalypse and palingenesis. ${ }^{20}$

This should, perhaps, come as no surprise, as it confirms a pattern already established in the research on fascist movements in other countries. If we focus on the temporal order that organised NS ideology, a hypothesis soon reveals itself. Just like the Italian Fascist movement, the German NSDAP, and the Romanian Iron Guard, the Ns combined a vision of a futural radical upheaval and palingenesis with a myth of an idealised past. It was futural, in the sense that the discourse of NS ideologues was dominated by portrayals of themselves as a forming a movement that was going to explode the status quo and precipitate revolutionary change. Like their fascist counterparts in other countries, they wanted to overturn what they saw as dividing features of Norwegian society. Liberalism and parliamentarism, Marxism and class conflict were all considered forces that divided the nation into opposed camps, based on competing interests. ${ }^{21}$ At the same time, however, they rooted themselves in the past, in a myth of an organic, atemporal ethnic nationalist community with its own secular eternity, ${ }^{22}$ more often than not evoked through images gathered from the Viking Age and the High Middle Ages. For instance, the leader of NS, Vidkun Quisling (1887-1945), imagined that his movement, if given power, would reverse the effects and values of the French Revolution ${ }^{23}$ and recreate

See in particular Alexander's analysis of Steve Bannon's ideology: Jeffrey C. Alexander, 'Raging against the Enlightenment: The Ideology of Steve Bannon,' Section Culture, August 18, 2017, https://asaculturesection.org/2017/08/18/ raging-against-the-enlightenment-the-ideology-of-steven-bannon/.

For instance, in their party program, penned in 1934, they evoked an image of Norway as standing in the midst of radical upheaval, where a decisive battle between nationalist and 'spiritual' forces was pitted against the deadening materialism of liberalism and Marxism: 'Norway is in the midst of a fateful upheaval. Dragged into the general world crisis, split and weakened in class struggle and party struggles, with heavy-handed and unstable governance, the Norwegian people now stand at a crucial crossroad.' Nasjonal Samling, Program for NS (Oslo: Thuleselskapet 1940), 3. All translations from Norwegian are mine, unless otherwise indicated.

22 Roger Griffin, 'Fixing Solutions: Fascist Temporalities as Remedies for Liquid Modernity,' Journal of Modern European History 13, no. 1 (2015): 5-23. The paradoxical temporality of a futurity anchored in a mythicised past lies at the heart of Griffin's argument that fascism is to be seen as a form of modernism in Modernism and Fascism: The Sense of a Beginning under Mussolini and Hitler (Basingstoke: Palgrave, 2007). See also: Roger Griffin, 'Building the Visible Immortality of the Nation: The Centrality of "Rooted Modernism" to the Third Reich's Architectural New Order,' Fascism: Journal of Comparative Fascist Studies 7 (2018), 9-44, https://doi.org/10.1163/22116257-00701002.

23 Hans Fredrik Dahl, De store ideologienes tid: Norsk idéhistorie, vol. 5 (Oslo: Aschehoug, 2001), 289 . 
past glory, by reconnecting the present with 'threads leading back to ancient Norway'. ${ }^{24}$ This is a phrase reminiscent of the idea proposed by the revolutionary conservative Arthur Moeller van den Bruck in his key work of historical analysis, Das dritte Reich (1923): 'eine Wideranknüpfung nach vorwärts', ${ }^{25}$ a reconnection forward. And it is a vision that was based on the assumption of the existence of an organic nation that stretched out and encompassed the past, the present and - even - the future. ${ }^{26}$

Thus, like similar movements in Germany, Italy and Romania, the NS was bent on creating a rooted modernity, and their ideology and conception of history thus oscillated 'between the seemingly opposing poles of revolution and eternity,'27 to borrow a phrase from Raul Carstocea's research on the Romanian Iron Guard. It revolved around an idea of the revolutionary rebirth of a mythical atemporal people, whose true values had been suppressed in recent history, but still lay 'slumbering' in the people. For example, the Fascist myth of romanità called for contemporary Italians to discover inside themselves their heroic destiny as modern Romans and so bring about Italy's rebirth from decadence. This oscillation between an idealised past and a futural rebirth of the kind identified by Griffin, underpinned the Ns party program and agitation, as well as the speeches of its most important ideologues, such as Quisling and Gulbrand Lunde (who served as the NS head of propaganda and minister of culture). However, the clearest expression of this oscillation between revolution and eternity is perhaps found in the NS's cultural production. In the propaganda posters produced by their most important illustrators, Harald Damsleth (19061971) and Kaare Sørum (1911-1982), blond, idealised members of the Ns were often portrayed as contemporary descendants of Vikings. ${ }^{28}$ Another example, is found in the works of the national socialist poet, Kåre Bjørgen (1897-1974), who during the Second World War produced several poems built around a palingenetic myth of the future resurrection of the values of an imagined, past Norse Golden Age. An example of this, is the poem 'Ein norrøn vår' ['A Norse Spring'], where Bjørgen used the allegory of seeds hidden in the frozen ground

Vidkun Quisling, For Norges frihet og selvstendighet: Artikler og taler 9. april 1940 - 23. juni 1941, vol. 3 (Oslo: Gunnar Stenersens forlag, 1941), 43 .

Arthur Moeller van den Bruck, Das dritte Reich (Hamburg: Hanseatische Verlagsanstalt, 1931), 163. See also: Griffin, Modernism and Fascism, 132.

For more on this aspect of fascist temporalities, see: Raul Carstocea, 'Breaking the Teeth of Time: Mythical Time and the "Terror of History" in the Rhetoric of the Legionary Movement in Interwar Romania,' Journal of Modern European History 13, no. 1 (2015): 81. Ibid.

28 See for instance: Hans Fredrik Dahl and Tom B. Jensen, Parti og plakat: NS 1933-1945 (Oslo: Historisk forlag, 2011), 161, 181, 188, 208, 210, 253. 
to envision a coming resurrection of past Norse greatness which in Weberian terms would re-enchant the world. With such allegories, Bjørgen was able to portray Norwegians as carriers of slumbering greatness - and fascism as answering a 'thousand-year-old longing' ${ }^{29}$

This basic structure, this hybrid temporality of revolution and eternity, also informed the worldview of Quisling. The Norwegian past, he claimed, was to serve as a model for the future. Yet, that did not mean that he was mere 'conservative' or 'reactionary', that he wanted to return to the past. Rather, like Mussolini and Hitler, he wanted to retrieve the values from an imagined and idealised past in order to construct a futural Utopia in a new historical context. ${ }^{30}$

\section{The Regime of Historicity Organising Ns Ideology}

Although we find the pairing of 'revolution and eternity' in the worldview of the NS - a pairing that Griffin, Esposito, Reichardt, and Carstocea have utilised to disclose the hybrid temporality of the fascist movements ${ }^{31}$ - Hartog's notion of 'regimes of historicity' can also help us identify how the fascist temporality is actually following a threefold structure. Despite internal ideological differences in the party - to which we will return below - there is an abundance of examples that show that a threefold structure of (i) a (mythic, ahistorical) fantasy of past greatness in primordial purity, followed by (ii) decay and decadence, brought about by the influence of racial, national, religious or ideological enemies, and (iii) a vision of a future rebirth of the national, cultural or racial community, characterised the way in which the NS - and people related to the party and its ideology - linked together the categories of past, present

29 Kåre Bjørgen, I Noregs namn (Oslo: Kamban forlag, 1940), 105-106; Kristian Aurebekk Andersen, 'Ein Norrøn vår: Norsk Nasjonalsosialistisk lyrikk' (Master thesis, University of Oslo, 2009), 37.

This often implicit structure is laid bare in a speech he held in 1934, where he first outlined the importance of the past for the way his movement situated itself in time: 'In contact with the past, we find the power for today's struggle and for the future', the leader of Nasjonal Samling claimed - before he was careful to stress the following: 'But our eyes are fixed forwards, to the new society that is going to be built. The new day calls for a new fight and for new deeds.' The quotation is taken from a speech Quisling held in 1934, quoted in Program for Nasjonal Samlings 8. riksmøte, Oslo 25-27 September 1942 (Oslo: Nasjonal Samlings rikstrykker, 1942), 13.

$31 \quad$ Fernando Esposito and Sven Reichardt, 'Revolution and Eternity: Introductory Remarks on Fascist Temporalities,' Journal of Modern European History 13, no. 1 (2015). 
and future. Alternatively, if this national, cultural or racial rebirth failed to materialise, they envisioned that the people would face destruction.

With that being said, however, it should be stressed that the Ns conception of history was not static. While this article tries to outline a temporal order that unifies the different periods and fractions of the Ns's lifetime, it should still be pointed out that the party had different ideological foci during their lifetime, and that its official ideology was a syncretic mix of different currents within the party that competed over hegemony. The history of the party can roughly be divided into three periods. First is the period from 1933 to 1935 , when the NS above all espoused an idealist, anti-materialist vision of history, and Marxism in general and the social-democratic Labour party in particular, represented their main ideological antagonists. ${ }^{32}$ In this period, the Ns repeatedly evoked an image of Norway as facing an impending rupture in historical time, where an age of materialism (characterised by parliamentarism and class struggle) were to be replaced by a new spiritual and idealist era (led by the Ns itself). ${ }^{33}$ According to the Ns, Marxism and liberalism had institutionalised conflict through parliamentarism and class struggle, thus tearing the national unity asunder and leading 'the cultural community towards destruction' ${ }^{34}$ As an alternative, the Ns claimed in the program penned in 1934 that their own nationalist movement represented healthy, spiritual and unifying principles that answered 'the people's longing for a new and better era., ${ }^{35}$

Second is the period from 1935 to 1939, when the NS was increasingly radicalised, while a profound antisemitism was added to their traditional anti-materialism with increasing intensity. ${ }^{36}$ Perhaps as a result of the fact that their prospects of ever becoming the populist mass movement that their rhetoric suggested petered out, the party eventually changed its tactics: After only managing to get $1.8 \%$ of the votes in the 1936 election (where they had believed that they would bounce back from the embarrassing 1933 election, when they only managed to get $2.2 \%$ of the votes), the Ns no longer tried

Hans Olaf Brevig and Ivo de Figueiredo, Den norske fascismen: Nasjonal Samling, 1933-1940 (Oslo: Pax forlag, 2002), 130; Dag Olav Bruknapp, 'Ideene splitter partiet: Rasespørsmålets betydning i Ns' utvikling,' in Fra idé til dom: Noen trekk fra utviklingen av Nasjonal samling, ed. Stein Ugelvik Larsen and Rolf Danielsen (Bergen: Universitetsforlaget, 1976), 19.

Brevig and Figueiredo, Den norske fascismen, 130. This typically fascist concept of living through the water-shed between an age of materialism and an age of restored heroism is explored with remarkable prescience in Peter Drucker's The End of Economic Man: A Study of the New Totalitarianism (New York: John Day, 1939). Ibid.

Hans Fredrik Dahl, Quisling - en norsk tragedie (Oslo: Aschehoug forlag, 2012), 182. 
to become a mass movement. Rather, the party became more sectarian and now restructured into a revolutionary vanguard party. ${ }^{37}$

This development can be interpreted in both a national and a transnational perspective: Although the NS always stressed that it represented an independent Norwegian phenomenon and not merely a copy of Italian Fascism and German Nazism, their own self-presentation should not be taken at face value. Rather, despite the fact that there was little direct contact between the NSDAP and the Ns before $1938,{ }^{38}$ the introduction of antisemitism should - as Martin Kristoffer Hamre has argued - be seen in a transnational perspective as the result of a growing identification with the NSDAP. ${ }^{39}$ On a more national level, however, it may also be interpreted in light of the fact that their main antagonist, the Labour Party, formed a government in $1935 .{ }^{40}$ As the Labour Party (in contrast to Ns themselves) had accepted the parliamentary system and won over forty per cent of the electorate in both 1933 and 1936, to accuse them of secretly plotting for a Marxist revolution, may no longer have presented itself as a convincing strategy. Increased (negative) focus on Judaism and an interest in racial questions may thus offered itself for the NS as a way of carving out a residual political field for themselves. ${ }^{41}$

The third period in the history of the NS is from 1940-45. In this period, Norway was occupied by Nazi Germany and the Ns named the only legal party. In this role, the Ns went from being a minute organisation consisting of around two thousand members to a mass movement made up of 44,000 members at its peak. During the occupation, members of the party represented the majority of Reichskommisar Josef Terboven's provisional councilors of state between 1940-42, and then formed a collaborationist puppet-regime, headed by Quisling at the mercy of the German occupiers, from 1942-45. In collaboration with the occupiers, the NS now found themselves in a new situation, where they sought to bring their ideology into life through a 'nyordning' [new ordering] of Norwegian society. ${ }^{42}$ Inevitably, this period was characterised by

This evolution took place from 1937. Brevig and de Figueiredo, Den norske fascismen, 113. Hans Fredrik Dahl et al., Den norske nasjonalsosialismen: Nasjonal Samling 1933-1945 i tekst og bilder (Oslo: Pax forlag, 2009), 72.

Martin Kristoffer Hamre, 'Norwegian Fascism in a Transnational Perspective: The Influence of German National Socialism and Italian Fascism on the Nasjonal Samling, 1933-1933,' Fascism: Journal of Comparative Fascist Studies 8 (2019): 36-6o, https://doi. org/10.1163/22116257-0o8o10o3. See also: Dahl, Quisling - en norsk tragedie, 182.

Linz, 'Political Space and Fascism as a Late-comer.' Although this was the second time the Labour party formed a government, their first attempt lasted for only two weeks.

Bruknapp, 'Ideene splittet partiet,' 27-28.

Øystein Sørensen and Nik. Brandal, Det norske demokratiet og dets fiender: 1918-2018 (Oslo:

Dreyer forlag, 2018), 132. 
a tension between adaption to Germany and the NSDAP and a need for the NS to legitimise their own revolutionary project by trying to establish themselves as representing some sort of continuity in Norwegian history. ${ }^{43}$ Thus, the NS drew heavily on already existing national myths, but recoded them into their own narratives of how they were about to facilitate the triumphant rebirth of a country that allegedly had been poisoned by Judaism, materialism and class conflict.

This article pays special attention to the 'mature' ideology espoused by the NS in this third period. Later we will look at the 'official ideology' of the party in this period and place it in contrast to a pan-Germanic wing within (and outside of) the party. Yet, it should still be pointed out that in addition to these two wings, the Ns initially also had a strong Christian wing, that had embraced the NS' rhetoric of the need for a 'spiritual' awakening in order to wipe out materialism and the alleged anomie and decadence of modern societies. ${ }^{44}$ In the NS, this Christian wing saw a movement that would replace divisive parties and class conflict with a gathering of people in a national 'rassemblement ${ }^{45}$ on the basis of Christianity. For example, Kjeld Stub, who was one of the most notable figures of this Christian wing, claimed in 1934 that the Ns did not represent 'ordinary politics, but a new spiritual uprising, both of a religious and national nature'. Attacking 'the declining morality of our time', Stub argued that the NS desire to 'abolish class struggle' and parliamentarism was 'in harmony with the ideals of Christianity' ${ }^{\prime} 6$ However, the increased role exerted by antisemitism and racism from 1935 on, alienated people that had belonged to the Christian wing, and many of its most prominent figures, like Stub, left the party. ${ }^{47}$

With that being said, it should still be pointed out that the official ideology of the party mediated between the different currents that competed over hegemony. The result was ideological syncretism, where NS appropriated both Christian and Norse symbols in order to signal that they were bent on exploding the 'materialist' status quo and facilitating an ultranationalist rebirth of Norway. On one side, the party program stated that 'the core values of Christianity [must be] defended' ${ }^{\prime 48}$ and the Ns used the Cross of St. Olav as

\footnotetext{
43 Sørensen and Brandal, Det norske demokratiet og dets fiender, 145.

44 For an example of this rhetoric, see: Gulbrand Lunde, Kampen for Norge I: Skrifter, foredrag og avisartikler 1933-1940 (Oslo: Gunnar Stenersens forlag, 1941), 105-106. For more on this rhetoric, see: Robert O. Paxton, The Anatomy of Fascism (London: Penguin Books, 2004), 74.

46 Kjeld Stub, 'NS en religiøs og åndelig reisning,' Nasjonal Samling, September 13, 1934, 6.

47 Bruknapp, 'Ideene splittet partiet,' 39. Conversely, many of the most radical Nazis also left the party in the 1930s, on the grounds that NS was not radical enough in their eyes. Nasjonal Samling, Program for NS, 8.
} 
its emblem, a symbol that referred to the warrior-king Olav Haraldsson (c. 9951030) who Christianised and unified the country. ${ }^{49}$ On the other, the Ns also appropriated 'pagan' Norse terms and symbols, for instance calling the corporate chamber that they wanted to replace the parliament with 'Rikstinget', ${ }^{50}$ as well as portraying the ideal Norwegian as a heir of the Vikings, and repeatedly using runes in their publications and posters. As a practice of revitalising a glorified past, the Ns also named their military wing 'Hirden', the medieval name for the guards of the King, ${ }^{51}$ and greeted each other with a raised arm in combination with the phrase 'Heil og scel' (meaning 'Live - be unharmed - and be happy!'52). Despite obviously mimicking both the Fascist Roman salute and the Hitler salute, the Ns insisted that they were only reviving 'the old form of greeting in Norway', and that this form of greeting was 'the only natural for the tall, free men and women'53 of the north.

It should also be pointed out that although the introduction of antisemitism radicalised the Ns, they never changed their party program, nor left behind this extraordinarily simplistic narrative of an idealist and nationalist rebirth and restoration after a period of degeneration. Rather, the idealist rhetoric and the metaphysical belief that the world crisis represented a surface expression of a larger transition from a materialist to an idealist era - stayed with the party throughout its lifetime. ${ }^{54}$ One example of this, is how the poet Åsmund Sveen (1910-1963), who became an important cultural bureaucrat during the occupation, wrote as late as 1944 that he was 'a spiritualist and idealist' who saw the NS as a 'historical-political movement' that represented the final showdown with 'materialism' and 'four hundred years of rationalism'. Wrapping his idealism and racism in the fascist rhetoric of palingenesis, ${ }^{55}$ Sveen wrote that

This movement must give birth again [gjenføde/rebirth] to the world of the white man; otherwise the West is doomed. That the economic liberalism of the West, which has degenerated into unrestrained capitalism, is

Terje Emberland, 'Neither Hitler nor Quisling: The Ragnarok Circle and Oppositional National Socialism in Norway,' Fascism: Journal of Comparative Fascist Studies 4 (2015), 119, https://doi.org/10.1163/22116257-00402004.

It should, however, be pointed out that even the Norwegian parliament - called Stortinget - alludes the medieval ting.

$51 \quad$ Hamre, 'Norwegian Fascism in a Transnational Perspective,' 47.

$5^{2} \quad$ Den gamle norske hilsen: 'Heil og Scel!' (Oslo: Nasjonal Samling, 1941), 2.

53 Den gamle norske hilsen, 10.

54 Ibid.

55 See also: Dean Krouk, 'A Queer Fascism?' in 'Der vårgras brydder': Nye lesninger av Åsmund Sveens diktning, ed. Hans Kristian Rustad (Vallset: Oplandske Bokforlag, 2010), 63-9o, especially 82 . 
now facing abolition, is something everyone must realise. The Asiatic socialism of the East, Bolshevism, is philosophical materialism in practice. . .. One thing is certain - everywhere it signifies the hatred of God and the rebellion against the divine message. The people's only salvation from this demonic chaos is a new idealistic movement that seeks spiritual acknowledgement and stems from elemental religiosity. By movement I do not mean any kind of political party, I mean an innovative historical idea, an idea of God, a great wave in the sea of history. ${ }^{56}$

Yet, the evolution outlined above (1933-35, 1935-39, 1940-45) did indeed radicalise the NS - and their conception of history. New elements were added to their traditional anti-materialism and anti-socialism. In some of Quisling's darkest speeches, for instance, the Norwegian people were portrayed as locked in an apocalyptic battle with Jews. We will return to one of these speeches below, but first we may consider one he gave in 1941, as it not only uncovers the 'regime of historicity' espoused by the Ns during the occupation; ${ }^{57}$ it also highlights another trait of the radicalisation of NS: an intensified cult of the past. ${ }^{58}$

\section{'National Decay and National Resurrection'59}

The speech, entitled 'National Decay and National Resurrection', was delivered during the Nazi occupation of Norway, and went on to occupy an important role in its public profile, as one of the key texts that representatives of the party were schooled in. In a textbook for a course for new representatives of the party, the speech was highlighted as the most important text for anybody who wants to understand 'Norway in greatness and decay. ${ }^{60}$ The aim of the course was 'to clarify the historical and national foundation of the Ns, to show the right and duty of Nasjonal Samling to take over the governing of the country, and to penetrate some of the major tasks of the Ns resurrection of Norwegian

56 Åsmund Sveen, 'Hvorfor jeg er medlem av Ns,' Nationen, January 29, 1944, 2.

57 Hartog, Regimes of the Historicity, xv.

$5^{8}$ Bruknapp, 'Ideene spilttet partiet,' 24.

59 This section draws on arguments also developed in an in-depth analysis of this particular speech. See: Fredrik Wilhelmsen, 'National Decay and National Resurrection: The Semiotics of Quisling's Conception of History', in War and Semiotics: Signs, Communication Systems, and the Preparation, Legitimization, and Commemoration of Collective Mass Violence, ed. Frank Jacob (London: Routledge, 2020), 229-258.

6o Hallvard Tveiten, Studieplan i emnet Det nasjonale og historiske grunnlag for NS: NS Studieringer (Oslo: Ns Opplæringsavdeling, 1943), 6. 
social life. ${ }^{61}$ In the course material, a twelve-point syllabus was tailored around Quisling's conception of history, spanning through the categories of past greatness in primordial purity, decay and rebirth, identifying along the way liberalism and Marxism as forces of decay, the North-Atlantic (and in particular Greenland) as Norway's rightful Lebensraum, and Quisling's struggle to bring about revolutionary change:

1. Norway in greatness and decay.

2. The fight against the forces of division.

3. The poison of Marxism.

4. The nature of liberalism.

5. Our spiritual leaders and the new age.

6. The Bolshevik Plans of World Revolution.

7. Quisling's battle for Norway.

8. Northern Norway for Norway.

9. The Northern Arctic Ocean as Norway's living space

10. How the Ns program is being realised in the state.

11. Norway in Germanic partnership.

12. A great, free and happy Norway. ${ }^{62}$

The vision of history reflected here - which is exactly the one revealed in Quisling's 'National Decay and National Resurrection' - rejects other competing temporal signposts of modernity, in particular the socialist, liberalist, and humanistic linear narratives of gradual development and progress. Instead it imposes Quisling's threefold division of Norwegian history, summarised in his own words as 'past greatness, national decay in the present, and new greatness in the future. ${ }^{\prime 3}$ Here, history is not unfolding, progressing or declining in a linear fashion open-endedly, but reaching a 'turning point' or 'water-shed' 64 after which it will enter a new cycle of regeneration.

Furthermore, it contains a mixture of prophecy and periodisation, what Hartog calls a 'chronosophy'.65 First it splits time into three separate phases: The period between the eigth century to around year 1300 are labelled as a 'golden age', evoking the image of 'Norgesveldet' [The Realm of Norway],66 i.e. the mythic construction, widespread in nineteenth and early twentieth

\footnotetext{
61 Tveiten, Studieplan i emnet Det nasjonale og historiske grunnlag for NS, 5 .

62 Ibid., 6.

63 Quisling, For Norges frihet og selvstendighet, 74.

64 Griffin, The Nature of Fascism, 35.

65 Hartog, Regimes of the Historicity, 11.

66 Quisling, For Norges frihet og selvstendighet, 145.
} 
century historiography, of Norway as a powerful nation in the Viking Age and in the High Middle Ages. ${ }^{67}$ The period from around year 1300 and all the way up the present is then labelled as a time of 'decay', where Norway first lost its sovereignty (due to the unions with Denmark and Sweden), and later, when it regained its independence as late as 1905 , came under the negative influence of the materialist ideologies of Judaism, liberalism and Marxism. ${ }^{68}$

But then the periodisation is supplemented with a prophecy - the promise of 'new greatness in the future'. As such, the speech did not so much serve the purpose of understanding what had happened earlier in history. Rather, the past was used in order to mobilise energies towards this third, coming historical era - a period that, in line with the tropes referred to earlier of apocalypse and palingenesis, were to resurrect the heroic values and imagined greatness of the Middle Ages in a new era. The prophetic nature of Quisling's regime of historicity was made evident when he connected the ancient past to the future, with the claim that the past contained 'a prophecy about the battle we are fighting today'.69 As such, the history of Norway was reconstructed only to the extent that the past could provide support for this paradoxical revolutionary thrust towards an utopian future. ${ }^{70}$

As the central role ascribed to this palingenetic narrative of Golden AgeDecay-Rebirth in the course material indicates, Quisling was not the only one in the NS who emplotted ${ }^{71}$ Norway's history into this regenerative structure: Gulbrand Lunde (1901-1942), who served as minister of culture under the occupation, also evoked this conception of history. ${ }^{72}$ Like Quisling, Lunde drew on the myths of Norgesveldet, and portrayed Harald Hårfagre's (ca. 850-932) unification of Norway and Håkon Håkonsson's (1204-1263) rule in the High Middle Ages as two high-water marks of history - before decay set in, first in the Danish era, and then, under the negative influence of liberalism, Marxism, and capitalist modernity. ${ }^{73}$

67 Øystein Sørensen, Hitler eller Quisling: Ideologiske brytninger i Nasjonal Samling 1940-1945 (Oslo: Cappelen, 1989), 31.

68 Quisling, For Norges frihet og selvstendighet, 84. See also: Wilhelmsen, 'National Decay and National Resurrection,' 229-258.

69 Quisling, For Norges frihet og selvstendighet, 74.

$70 \quad$ Griffin, 'Fixing Solutions,' $5^{-23}$. See also: Wilhelmsen, 'National Decay and National Resurrection,' 229-258.

71 See Paul Ricœur, Time and Narrative, vol. 1 (Chicago: University of Chicago Press, 1984).

72 Sørensen, Hitler eller Quisling, 31.

73 Ibid. See also: Gulbrand Lunde, Kampen om Norge II: Foredrag og artikler 1940-1941 (Oslo: I kommisjon hos Gunnar Stenersens forlag, 1942), 87. 


\section{Plural 'Histories' and 'History' in the Singular}

As Reinhart Koselleck's and Zygmunt Bauman's analyses of the shifting of our collective experiences of time tell us, the manner in which Quisling and Lunde perceived themselves as standing in the midst of a historical transition between two worlds, is characteristic of the perception of temporality in modernity. ${ }^{74}$ However, the relationship between Quisling's and Lunde's triadic schemes and the modern concept of history is a peculiar one. On one hand, their New Order, that they imagined would recreate past glory, was supposed to tie its 'threads back to ancient Norway'.75 At the same time, however, the goal of the New Order was to transcend existing society, to establish something completely new: a new temporality and what Peter L. Berger calls a new nomos. ${ }^{76}$ This vision seemingly alternates between a modern and a pre-modern scheme of history. In Koselleck's analyses, modernity is characterised by a perception of time and history which replaces the plural Geschichten [histories] with Geschichte [history] in the singular. According to Koselleck, this change involved abandoning a vision of the past as historia magistra vitae, i.e. a vision in which past events and individuals were thought of as exemplary models to be imitated in the present. In its place came a notion of history as a process, with its own temporality and dynamics. Due to the rapid changes witnessed, especially after the French Revolution, a gap between the 'space of experience' and the 'horizon of expectation' opened in modernity. ${ }^{77}$ Rather than looking for the exemplum, energy was now devoted into defining the uniqueness of the event, recognising that the past must be understood in relation to its context, ${ }^{78}$ but, more importantly, that 'all previous experience might not count against the possible otherness of the future. 79

While Quisling operates within a modern concept of history in the singular, he also treats history as historia magistra vitae. With his notion of a past 'golden age', Quisling's conception of history revolved around the exemplary character of figures such as Harald Hårfagre (ca. 850-932), Håkon Håkonsson (1204-1263), and Olav Haraldsson (995-1030). In an attempt to provide legitimacy for his anti-democratic politics, he drew on myths surrounding Olav

Koselleck, Futures Past, 246; Zygmunt Bauman, Liquid Times: Living in an Age of Uncertainty (London: Polity Books, 2007), 96. Quisling, For Norges frihet og selvstendighet, 43.

76 Peter L. Berger, The Sacred Canopy: Elements of a Sociological Theory of Religion (New York: Anchor Books, 1990).

$77 \quad$ Koselleck, Futures Past, 267.

78 Hartog, Regimes of the Historicity, 73 and 104-105.

$79 \quad$ Koselleck, Futures Past, 267.
} 
Haraldsson and Harald Hårfagre, and wrote that just as Norway was united and Christianised by force, his fascist rule was only going to be able to resurrect past greatness through the use of force: 'All legitimate means must be used if [the policy] it is to have an effect, and since people, as a rule, only have understanding and respect for power, one has to use power in order to establish the rule of law and a bring about the resurrection of the country. Norway was united by power. And it became Christian by power. ${ }^{80}$ Instead of seeing him as tied to the historical context of the Viking Age, Lunde and Quisling repeatedly portrayed Harald Hårfagre as a someone whose actions could be imitated today. ${ }^{81}$ Seeing the past as a model for the future, Lunde argued that the past held the key to unlock the present. On the day of the battle that allegedly took place in Hafrsfjord in 872 according to a widespread national myth that sees this battle as resulting in the unification and 'Birth of Norway', Lunde gave a speech in 1941. Here Lunde presented the idea that the battle that Harald Hårfargre fought ' ', o6o years ago', was the same Quisling fought today, i.e. a battle between uniting and dividing forces. In this symbolic narrative, Quisling represented Harald Hårfagre, while democracy, the Labour Party and the Conservatives represented the same 'divisive forces' as Hårfagre had combated in 872 - forces that allegedly put their own interests above that of the people and kingdom as a whole.'82

This narrative contained not only a historical motive, but also a political one. The governmental structure of Norway had to be based on what was unique and distinctive about the nation, Quisling and Lunde argued. 'What have democracy and party politics to do with the Norwegian character?'83 Lunde asked rhetorically in an attempt to provide legitimacy to the Führerprinzip. Rather than the alternatives 'democracy and British parliamentarism' or 'Jewish Marxism and Bolshevism, 84 the Ns saw the notion of a Führer as something essentially Norwegian - and the answer was to be found in figures like Harald Hårfagre. Rather than copying a governmental structure from Germany or Italy, they argued that the Führerprinzip would represent a re-establishment of

\footnotetext{
8o Quisling, For Norges frihet og selvstendighet, 92.

81 See also the analysis in: Wilhelmsen, 'National Decay and National Resurrection,' 229-258.

82 Lunde, Kampen for Norge II, 87. This argument is also supported by the fact that instructors of the aforementioned course in the historical and national foundation of NS were urged to 'provide some clear expressions of national decay from the years 1920-1940 by contrasting them with Norway's Golden Age around 8oo-1319.' See: Tveiten, Studieplan i emnet Det nasjonale og historiske grunnlag for NS, 8.

83 Quoted in Sørensen, Hitler eller Quisling, 44.

84 Lunde, Kampen for Norge II, 85 .
} 
the leadership principles that had defined Norway's Golden Age. ${ }^{85}$ Moreover, although they wanted to reverse the effects of the French Revolution, the NS claimed that their attempt at remodelling Norwegian society into a fascist corporative state, was true to the constitution of 1814 - a constitution inspired by the French Revolution that they elsewhere portrayed as the source of modern decadence. By claiming that they were only removing things that had been added since 1814, most notably parliamentarism, the Ns tried to present the New Order as a restoration of the past, and the Führerprinzip as providing an 'organic link' between 'all [the] revolutionary upheaval's6 they had initiated and the original constitution.

\section{Coming Full Circle: The Pan-Germanic Wing}

However, there were also other competing conceptions of history - and hence, of how the future should unfold - in and around Ns. As Øystein Sørensen and Terje Emberland have shown, a key question divided the party: the question of whether their movement should be a nationalist or a pan-Germanic one. ${ }^{87}$ This question had already divided the party in the 1930s, but it obviously became a more crucial debate during the occupation. The nationalist wing, headed by people such as Quisling and Lunde, wanted to have a close relationship with Germany, but emphasised that Norway had to be an independent state. They believed that the Ns leadership were the only ones capable of landing a peace agreement with Germany, and that Quisling then would become the Führer for an independent Norway within a New European Order headed by Germany. ${ }^{88}$ Their way of welding together the past, the present and the future, reflected both this (ultra)nationalist stance and the Ns's inevitable tension between adaption and self-assertion during the occupation. However, opposed to the hegemonic wing represented by Quisling and Lunde stood a pan-Germanic

85 Sørensen, Hitler eller Quisling, 44. See also the analysis in: Wilhelmsen, 'National Decay and National Resurrection,' 229-258.

86 Vidkun Quisling, Quisling har sagt. Vol. IV: Mot nytt land (Oslo: Blix forlag, 1944), 129, quoted in Sørensen og Brandal, Det norske demokratiet og dets fiender, 145.

87

The following section about pan-Germanism is mainly based on Øystein Sørensen, Hitler eller Quisling, 12f. It also draws on Terje Emberland, Religion og rase: Nyhedenskap og nazisme i Norge 1933-1945 (Oslo: Humanist forlag, 2004), 111f., as well as Terje Emberland and Matthew Kott, Himmlers Norge: Nordmenn i det storgermanske prosjekt (Oslo: Aschehoug, 2012), 99 .

88 Leif Ove Larsen, 'Erfaringer med det totalitære: 1940-1945,' in Allmenningen: Historien om norsk offentlighet, ed. Jostein Gripsrud (Oslo: Universitetsforlaget, 2017), 308. 
faction, who were prepared to absorb the Norwegian people into a 'Greater Germanic Reich' to a far wider extent. ${ }^{89}$

These differences led to a modulation of the regime of historicity that was evoked. Even though notions of a common Nordic or Germanic race also informed Quisling's conception of history, it was more in terms of 'brotherhood'90 and his main historical subject was always the Norwegian people. The pan-Germanists, however, wanted to reattach Norwegians to what they believed was their true racial community. ${ }^{91}$ This led to a different foundation myth - a 'historical' (linked to a specific period) and a 'primordial' one: While Quisling and Lunde evoked a myth of a past golden age, the pan-Germanist cult of the past to a larger extent revolved around the roots and genealogy of Germanic people, than of a more tangible historical period. By reconnecting Norwegians with their organic Germanic roots - as these were allegedly allowed to express themselves before there existed any borders - Norwegians would be able to recapture their true Germanic identity and regenerate themselves, the pan-Germanists believed. In an age characterised by industrialisation and class struggle, such a revolutionary upheaval in the name of the Germanic race was imagined as something that would reintegrate the individual into his and her true community, by overturning the forces that allegedly had pitted different social classes against each other: Marxism, liberalism, materialism, democracy and Judaism. If contemporary Norwegians could reconnect with this heroic pagan past, the pan-Germanists believed they could recapture their true identity. ${ }^{92}$ To create 'The Great unification of the Nordic or Germanic race' 93 will be the 'biggest and proudest' achievement of Norwegians, one of the key ideologues within the pan-Germanic current, Quisling's minister of justice and Standartenführer in the $s s$, Sverre Riisnæs, ${ }^{94}$ argued - adding that it would represent an 'expansion of our community to secure our blood and our soil.'95

This desire to re-root Norwegians in a greater Germanic race - and, by doing so, transform an allegedly widespread feeling of anomie and alienation with one of belonging - was, however, not something the Norwegian pan-Germanists came up with in isolation. ${ }^{96}$ First of all, they espoused ideas

\footnotetext{
89 Sørensen, Hitler eller Quisling, 47.

$90 \quad$ Quisling, For Norges frihet og selvstendighet, 118.

$91 \quad$ Emberland, Religion og rase, 111f.; Emberland and Kott, Himmlers Norge, $99 \mathrm{f}$.

92 See for example: Sverre Riisnæs, Nasjonalsosialistens livssyn: Vårt grunnlag og vår pakt med naturlovene (Oslo: Kamban forlag, 1943).

93 Riisnæs, Nasjonalsosialistens livssyn, 32.

94 Sørensen, Hitler eller Quisling, 22.

95 Riisnæs, Nasjonalsosialistens livssyn, 29.

96 Mosse, Nazi Culture, xxi.
} 
similar to the ones disseminated by the key ideologue of the German NSDAP, Alfred Rosenberg. ${ }^{97}$ The latter had argued that common blood made the Germanic or Nordic race into an 'organic' community, united in both the past, the present and the future. ${ }^{98}$ The Norwegian pan-Germanists could speak in a similar metaphysical language to Rosenberg's, claiming that common blood made present-day Norwegians part of 'an infinite chain' of Germanic people, 'an organism that lives forever - with hundred generations in front of us and after us. ${ }^{99}$

Secondly, the pan-Germanists accommodated central parts of the ideology of the $s s$, and, as such, it is no coincidence that Riisnæs was a prominent spokesman for pan-Germanism, as well as one of the architects behind the establishment of the Norwegian branch of Germanic-ss (Germanske ss Norge), where he served as a deputy leader. Inspired by the völkisch movement's idea of an intimate connection between the 'race' and the landscape, Himmler had voiced narratives of Norwegians as a distinctly racially pure people - with a strong sense of honour - within the Germanic race. ${ }^{100}$ This myth was not only welcomed by Riisnæs, but also by the so-called Ragnarok circle, which - as Emberland has outlined ${ }^{101}$ - consisted of people associated with the NS who represented a radical, neo-pagan and pan-Germanic opposition to the 'nationalist' hegemony inside the party. The narrative of Norwegians as a distinctly pure version of the Germanic race fitted snuggly with the Ragnarok circle's desire to inaugurate a new era by integrating Norwegians into a greater Germanic Volk. ${ }^{102}$ Inspired by the far-right author Erling Winsnes (1893-1935), this circle saw Norwegians as the most developed part of the Germanic race, due to the harsh living conditions of the north. When the glaciers withdrew after the Ice Age, Winsnes argued, those who went on to become Norwegians decided - in contrast to their Danish and German 'brothers' - to follow the ice. Living far north, Winsnes and the Ragnarok circle thought that Norwegians were exposed to dangers that their fellow brothers on the continent were

97 Alfred Rosenberg, The Myth of the Twentieth Century (Ostara Publications, 2018).

98 Førland, Nazismens idéunivers, 192-208.

99 Riisnæs, Nasjonalsosialistens livssyn, 13. Note the marriage of diachronic/historical and synchronic/eternal time.

100 Terje Emberland and Matthew Kott, Hitlers Norge: Nordmenn i det storgermanske prosjekt (Oslo: Aschehoug forlag, 2013), 56.

101 Emberland, Religion og rase, 111f; Emberland, 'Neither Hitler nor Quisling', 121.

102 For more on the Ragnarok circle, see: Emberland, 'Neither Hitler nor Quisling,' 119-133; Emberland, Religion og Rase. 
spared, and that this consequently led to Norwegians growing tall, becoming strong and developing a strong sense of honour. ${ }^{103}$

The Ragnarok cirle also perceived Quisling as being too 'bourgeois', and through his defence of 'Christian values' - too influenced by 'Semitic' ideas. For instance, the editor of Ragnarok, Hans S. Jacobsen, despised the use of the cross of St. Olav as the official symbol of the NS as it established a connection between the (myth of the) coming rebirth of the race and the Christianisation of Norway. The cross of St. Olav 'is an expression of a universalist idea', Jacobsen claimed, polemically stating that Quisling had 'planted ... the Cross of St. Olav in Norway in an act of adultery against his own true nature.'104 In opposition to Quisling, the Ragnarok circle wanted to shuffle the cards. The Ns should not limit itself to be an authoritarian Christian-nationalist movement, bent on reducing the spiritual and cultural decay of modernity. Rather, they wanted, as Emberland has argued, to be 'the avant-garde of a National Socialist revolution. ${ }^{105}$ In their view, this revolution would have to be based on what is best described as a racist conception of history, where the struggle between different races was the lens through which history was filtered. ${ }^{106}$ In the columns of Ragnarok, Christianity was seen as a artsfremmed ['species-alien'] influence on Norway, an influence which had 'committed murder on the inner life of the race' by introducing 'southern and alien ideas' 107 to Germanic countries. Instead, figures like Jacobsen embraced paganism, since Norse mythology had its origins in the Nordic countries, and hence, he thought, was true to the Nordic spirit.

Emplotting the past, the present and the future into the matrix of past greatness in primordial purity-decay/decadence-future rebirth or annihilation, pan-Germanists like Jacobsen (and Riisnæs) wanted to restore the virtues of an ancient Germanic past, by creating a 'Greater Germanic Reich', thus coming full circle, leading back to the 'original' source, while at the same time realising something completely new. Writing in 1943, Jacobsen evoked the Germanic 'blood' as a carrier of a collective racial consciousness, and portrayed those who fought and died for national socialism as 'true to their ancestry and their

103 Emberland, 'Neither Hitler nor Quisling,' 123. See also: Erling Winsnes, Til en ukjendt gud: Slegternes vekst, blomstring og undergang (Kristiania: Cammermeyer, 1919); Erling Winsnes, Den neste stat (Oslo: Fabritius \& Sønners Forlag, 1925). This idea of growth through living with danger was also essential for Riisnæs, who argued that the struggle for existence was a life-enchanting principle and the most important law of nature. Hans S. Jacobsen, 'Vidkun Quisling og N.S.', Ragnarok, no. 3, 1937, 6 o.

105 Emberland, 'Neither Hitler nor Quisling,' 121.

106 Ibid., 122; Emberland, Religion og rase, 111.

107 Jacobsen, 'Vidkun Quisling og N.S.,' 6o. 
people', as loyal 'to their blood', since they placed themselves in a long line of people fighting for the Nordic race - and, as such, formed 'a bridge between the past and the future.'108

\section{Matter out of Place, Time out of Joint}

All the different historical narratives encountered share a diagnosis of the current situation as one of crisis and decline, coupled with an intense nostalgia for an imagined past community. However, they also share an expectation for the future that is grounded in 'a revolutionary temporality of renewal' 109 and regeneration. Although the pan-Germanists in and around the NS believed that Norwegians would recapture their true identity by reconnecting with its Germanic and/or pagan past, it should be pointed out that their vision of history (like Quisling and Lunde's) was still future-oriented: They evoked metaphysical notions of Nordic 'blood' and a pagan Germanic past in order to give flesh to a vision of an alternative rooted modernity ${ }^{110}$ that would provide remedies for the alleged deterioration and alienation caused not only by the universalist principles of Christianity, but also by what sociologist Ferdinand Tönnies conceptualised as a shift from (organic) Gemeinschaft to (contractual) Gesellschaft. ${ }^{111}$ Although rejecting what was labelled the 'frenzy of progress' 112 and the belief in the superiority of 'the modern man,'113 the pan-Germanists dream was to re-awake the values of the past in order to open up a path to an alternative modernity, freed of the alleged erosion of natural instincts and traditional values in actually-existing modernity. ${ }^{114}$ In Nazism, Jacobsen of Ragnarok for instance saw a movement that had 'put an end to the age of the French Revolution, and ushered in a new century in human history. 1789 and 1933.'115

The structure of past greatness-decay-rebirth can also be seen as organising historical events and agents in accordance to a set of symbolic distinctions or

\footnotetext{
108 Hans S. Jacobsen, 'Ved Per Imerslunds bålferd,' Ragnarok, no. 9-10, 1943, 225.

109 Peter Osborne, The Politics of Time: Modernity and the Avant-Garde (London: Verso Books, 1995), 163.

$110 \quad$ Griffin, Modernism and Fascism, 244.

111 Ferdinand Tönnies, Community and Civil Society (Cambridge: Cambridge University Press, 2001); Emberland, Religion og Rase, 400.

112 Riisnæs, Nasjonalsosialistens livssyn, 22.

113 Ibid.

114 See for instance: Riisnæs, Nasjonalsosialistens livssyn, 23.

115 'Hvad blev De mest overrasket av i fjor?' Moss Avis, 21 January 1934, 2.
} 
boundaries of the kind investigated by anthropologists such as Mary Douglas and cultural sociologist such as Alexander and Smith, namely between the pure and the impure. ${ }^{116}$ According to Douglas, we perceive things contained within their own category as pure, while we conceive 'matter out of place' as impure, polluted and dirty. ${ }^{117}$ Hence, impurity is often associated with chaos and dissolution, and perceived as something threatening. As such, Douglas' distinction may offer a framework to interpret the prevailing sense of 'crisis', 'degeneration' and 'decadence' (and what Hitler referred to in Mein Kampf as Zersetzung [dissolution]) encountered in the Ns vision of history. First of all, it can help us recognise how the movement from Golden Age to Decay is codified as a movement from something that is contained within its category, i.e. as something pure, to something chaotic and in a process of dissolution, i.e. as something 'out of place', spatially and temporally, an experience of time being 'out of joint' in contemporary history. Furthermore, the diagnosis of the present as an era marked by historical decay implicitly presupposes an original era in primordial purity, when Norway was Norwegian, when Norway was pure. We may also recognise how the narrative of a coming national rebirth - that reverses a period of decay - can precisely be seen as a cleansing operation that is imagined to restore the internal harmony, vitality and dynamism of contemporary societies.

With that being said, however, it should be emphasised that the Ns construction - through historical narratives - of what Benedict Anderson has called an 'imagined community'118 at least partly overlaps with similar constructions both in other extremist movements, and in other softer, more liberal versions of nationalism. For instance, the idea, implicit in much far-right and fascist ideology, that each nation, each human community has a unique identity and shared history, different from its neighbouring communities, and each expressing its own 'core', relating to - and arising from - its local environment, was, of course, not something that first arose with fascism, nor with the Völkish movements that eventually went on to inspire fascist and Nazi-movements. ${ }^{119}$ Such organic concepts of the nation date at least dates back to nineteenth

116 Mary Douglas, Purity and Danger: An Analysis of Concepts of Pollution and Taboo (London/ New York: Routledge, 2001); Jorunn Solheim, 'Forord,' in Rent og urent: En analyse av forestillinger omkring urenhet og tabu, Mary Douglas (Oslo: Pax forlag, 1997), 10-11; Alexander, The Meaning of Social Life, 166; Smith, Why War?,14.

117 Douglas, Purity and Danger, 36.

118 Benedict Anderson, Imagined Communities: Reflections on the Origin and Spread of Nationalism (London: Verso Books, 1983).

119 George L. Mosse, The Crisis of German Ideology: Intellectual Origins of the Third Reich (New York: Howard Fertig, 1998). 
century romanticism, but had already found striking expression in the eighteenth century in Johann Gottfried von Herder's Reflections on the Philosophy of the History of Mankind, where the German Sturm und Drang intellectual questioned the modern idea of progress that assumed that people living in the present were necessarily living in better times than their predecessors, and postulated the idea that each people possessed a unique Volksgeist. ${ }^{120}$

In the case of the more nationalist narratives of history evoked by the Ns, a more direct influence comes from the specific Norwegian national romantic currents in the nineteenth century. In their different outlines of history, the NS drew heavily on romantic images and historical narratives that were hegemonic in the construction of the Norwegian national identity in the nineteenth century. During that whole century, tropes of a national rebirth were widespread. Like the Ns, these nineteenth century visions of a national rebirth of the Norwegian nation were built around the image of the Norse period and of the High Middle Ages as a Golden Age of the Norwegian people, with four hundred years of union with Denmark conceived as a period of decline and decay. For instance, the narrative of a Golden Age, that peaked in the thirteenth century but was superseded by a long period of national decline from around year 1300 , was a recurring theme in the scholarly reconstructions of the Norwegian past in the nineteenth century. Thus, the trope of decline after 1319 was not the exclusive property of the Ns, but the interpretive framework that determined the narrative of Norway's history in the works of historians who played decisive roles in shaping the historical consciousness of the Norwegian public, such as Rudolf Keyser (1803-64), P.A. Munch (1810-63), Torkel Halvorsen Aschehough (1822-1909), and Ernst Sars (1835-1917).121

Moreover, this vision of history that the ns built upon emplots the past in accordance with the classical temporal geometry of grandeur et décadence familiar, for instance, from the epic narrative of the rise and fall of the Roman Empire. ${ }^{122}$ This trope 'of living in a period of political and cultural decline'123 is in other words what Jeffrey C. Alexander would call a 'culture structure', and it is, as Koenraad W. Swart has pointed out, 'as old as recorded history,',124 and

Francis Fukuyama, Identity: Contemporary Identity Politics and the Struggle for Recognition (London: Profile Books, 2018), 6o; Carl Müller Førland, Nazismens idéunivers (Oslo: Vidarforlaget, 2017), 31-44. 1990); Steinar Imsen, Noregs nedgang (Oslo: Samlaget, 2002), 9. Imsen, Noregs nedgang, 7.

123 Koenraad W. Swart, The Sense of Decadence in Nineteenth Century France (Springer, 1964), 1. 
found even in the religious cosmologies of early civilisations. ${ }^{125}$ Furthermore, in the Ns own lifetime, this contrasting of blossom and decline, decay and rebirth, permeated the imaginaries of other fascist movements, as well as Oswald Spengler's The Decline of the West ${ }^{126}$ which stated a somewhat similar idea, but embedded it in an even more overarching cyclical philosophy of history according to which civilisations followed the evolutionary steps of biological life, passing through birth, flowering, decline and death. ${ }^{127}$

\section{An Apocalyptic Mode of Narration}

Yet, despite the similarities addressed, there are also key differences. The ideologues of the Ns recoded the culturally shared metaphors and codes just outlined - as well as the hackneyed trope of Norway's decline after 1300 - and integrated them into their own palingenetic, apocalyptic and antisemitic grand narratives. While drawing on already existing tropes, cultural archetypes, and conceptions of history, the NS wove them into their own fascist heroic scenario of palingenesis and apocalypse. The main difference thus lies in the subliminal plot structuring the conception of history. In NS narrative - as opposed to the scholarly reconstructions of Norway's evolution - neither internal factors, like the lack of a Norwegian nobility, nor the union with Denmark, were the real cause of the decline. ${ }^{128}$ Quisling and the Ns reconstructed the past in a manner that supported their own project of establishing an ultranationalist New Order. Past 'greatness' and contemporary 'decadence' were thus typified as being symptomatic of a larger struggle 'that runs through the whole life of the world ${ }^{\prime 29}$ in the ideology of the Ns.

The use of war-like metaphors and a prevailing sense of crisis was, of course, widespread in the 1930s, and not an exclusive feature of the NS or other fascist movements. The general sense of crisis and turning point, of living in a liminal time, was also common well beyond the ranks of the Ns - in Norway, as in the

125 David Engels, 'Oswald Spengler and the Decline of the West,' in Key Thinkers of the Radical Right: Behind the New Threat to Liberal Democracy, ed. Mark Sedgwick (Oxford: Oxford University Press, 2019), 7.

126 Oswald Spengler, The Decline of the West (New York: Vintage Books, 2006).

127 Engels, 'Oswald Spengler and the Decline of the West,' 7.

128 Nor was it Denmark or Sweden that were the main antagonists, the ones that served as a foil for Norwegian identity. Rather it was now England and Russia, and - more importantly - the materialist ideologies associated with these countries: Marxism (Russia) and liberalism (England). 
rest of Europe. ${ }^{130}$ For instance, claims that 'the death knell is sounding for liberal society' were not only emanating from Ns propagandists, but also from the Labour Party. ${ }^{131}$ As such, the NS was a child of its age.

Yet, the narrative logic that underpinned the Ns vision of history was distinct from other competing ideologies - and from the variants of grandeur et décadence expressed by Sars, Munch and others. It was not only a vision of history that pointed towards the historical and national foundations of the Norwegian people, thereby indicating the need for an independent Norwegian, national state. It also imposed another 'totalising nomos' 132 upon the flow of time and embedded history in an apocalyptic narrative logic. As already mentioned, Ns' political apocalypticism was at first envisioned as an idealist, spiritual and nationalist 'struggle against the materialist view of life', epitomised by Lunde in 1934 in Manichaean terms as 'an eternal struggle ... between the divine and the demonic, between that which wants a spiritual development and that which wants to dissolve and destroy, between love and hate, between the eternal and the temporal.'133 After 1935, however, this battle was recoded according to an antisemitic plot. In some of Quisling's darkest speeches and in the book The War of the Jews by the leading antisemite of the ns (and leader of their office for press and propaganda between 1935 and 1940), Halldis Neegård Østbye, the Norwegian and Nordic people were locked in an apocalyptic battle with the Jews. Making the semiotic constructions of, on one side, Judeo-Bolshevism, ${ }^{134}$ and, on the other, the international Judeo-Plutocratic plot, her own, Østbye for instance claimed that '[o]ur Nordic society has in the last generation been permeated by the destructive ideas of the Jews whether they came from the east with communism or from the west with liberalism.' ${ }^{135}$

Together with the rebirth myth and the trope of an estrangement from a past golden age, the apocalyptic logic structured the Ns's narration of history. As highlighted by literary theorist Northrop Frye and cultural sociologist Philip Smith, one of the key characteristics of the apocalyptic mode of narration is an intense character polarisation. Due to this polarisation, the protagonist in the given plot can only develop in a limited number of directions. In The Anatomy of Criticism, Frye distinguished between low-mimetic, tragic, romantic, and

130 Hans Fredrik Dahl, De store ideologienes tid: Norsk idéhistorie 1914-1955 (Oslo: Aschehoug, 2001), 167 .

131 Dahl, De store ideologienes tid, 173.

132 Berger, The Sacred Canopy, 20.

133 Lunde, Kampen for Norge I, 83.

134 Paul Hanebrink, A Specter Haunting Europe: The Myth of Judeo-Bolshevism (Cambridge: The Belknap Press, 2018). 
apocalyptic modes of narration. ${ }^{136}$ While the first three modes of narration are either nuanced and mundane (low-mimetic narration), fatalistic (tragic narration) or optimistic (romantic narration), Philip Smith has argued that the apocalyptic mode of narration is often used to justify draconian measures, for instance in cases of war. The reason, is that apocalyptic modes of narration make events seem 'unequivocally world-historical, and in need of heroic interventions, for the object of struggle is the future destiny of the planet or civilisation.' As such, '[a]pocalyptic narratives are the most effective at generating and legitimating massive society-wide sacrifice'.137

Moreover, drawing on Mary Douglas' distinction between the pure and the impure/polluted, ${ }^{138}$ Smith claims that apocalyptic narratives often pits 'us' against 'them' according to binary oppositions where '[t]hose encoded as pure and those encoded as polluted, must act in ways that sustain this imagined scripting.'139 If we turn to Østbye's The War of the Jews, we soon discover how this mode of narration - and the binary codes of the pure and the polluted - is deployed in the book: First, Østbye claims that Judaism signals a new form of warfare - a war that is no longer waged between states, but between different cultures and races. In this narrative, Jews are typified according to classic antisemitic semiotics as the archetype of the impure Other who cannot 'be assimilated' or 'merge with the country's own population', since they are seen as cosmopolitan, rootless, materialist and unnational, having 'their own morals, their own peculiar customs, their own religion and their own legal concepts - even a view of life that is contrary to the concepts of law and morality of all civilised states. ${ }^{140}$

Moreover, according to Østbye's apocalyptic narration, the 'whole history shows an unbroken chain of conflicts between Jews and non-Jews in almost every country'. In this narrative, contemporary reality was being actively shaped by a world-historical conflict of two enemy cultural and racial identities and worldviews which was now entering its endgame in which existential choices between conflicting value-systems had to be made:

The present crisis ... culminates in the battle between two views of life, the one with an emphasis on the Nordic-idealistic and the other the Jewish-materialist worldview. In a way, it is a battle between good and 
evil, as it has been from the dawn of time. But the difference is that never before in human history have such a concentration of money and media power, and such overpowering organisations, fuelled the destructive forces. ${ }^{141}$

In Østbye's apocalyptic narration of history, the 'great spiritual crisis that begun already with the French Revolution' has now entered 'its last phase.'142 Evoking a coming rebirth of the national community of the kind identified by Griffin with the palingenetic component of fascist myth, she envisioned a cathartic, cleansing operation that would reverse a period of decay and purge contemporary societies of impure matter, so that time and space, indeed history itself, was no longer out of joint:

To resurrect our people's high moral standards and save it from national annihilation can only happen by giving it a new content of life - by preaching a new idea that lifts the banner of idealism - which can replace the false doctrine of class struggle and godless materialism, and is stronger than it. It presupposes a new form of state based on cooperation, not on class struggle, - on the community of the people, not on party interests, - on the national principle, not on internationalism. A new order that prevents the continued undermining of our Nordic culture and morals, prohibits the spread of class hatred and anti-social agitation, protects our people from degeneration and alien rule by effective race protection laws, that resurrects a free and independent peasantry by pulling the land and forest out of speculation and tying it to ancestry of the genus - the entire emancipation of labour from international capital and gold. This, and much more, is the prerequisite for our country and our continent to be set free and purified from the international un-Nordic Jewish spirit that led us to misfortune. ${ }^{143}$

We find the same pairing of apocalyptic rhetoric with a cleansing palingenetic myth evoked by different ideologues of the NS, most notably in one of Quisling's most disturbing speeches, 'The Battle between Aryans and Jewish Power'. It was held at the opening of Alfred Rosenberg's Institute for Research of the Jewish Question in March 1941 in Frankfurt am Main. As the title indicated,

\footnotetext{
141 Ibid., 16o.

142 Ibid., 161.

143 Ibid., 164. Note that the rebirth is envisioned to be 'purified' (cf. Douglas' distinction between the pure and the impure).
} 
Quisling now shared Østbye's vision of the relationship between Norwegians and Jews as a world-historical battle. In the speech, Quisling portrayed Norway as a country about to inaugurate a new era by overcoming the 'the old' and decadent 'system'. Evoking the Norse myth of Ragnarok, Quisling argued that before the new dawn could burst forth, was that the archetypal enemy of the nation, the 'Jew', had to be defeated. Laying bare a Manichean vision of history, he claimed that the antagonisms in society had been simplified and 'in reality reduced to a duel between Judaism and the European principle':

Out of the national decay and breakdown that the Jews brought upon our people, a national resurrection is emerging. A new Norway rises on the solid foundation of national socialism and the principles of the Nordic race, working together with our brother people, the Great Germanic Reich, and determined to take our place in and work towards the new Europe, freed from England and Israel. This outcome will in a strange way realise the living idea contained in the ancient Nordic myth of a battle that runs through the life of the world between Aryan and Jewish power and which will end in one last great battle, Ragnarok, the darkness of the Aryans, caused by the Aryans accepting the Jews within their midst and as such weakening their divine power. But the world of the Aryans only goes under to be reborn greater than before. In the decisive battle, the world-serpent and the war-wolf are killed. The old goes under, and a new world breaks forth, populated by a more vigorous and happier human race. ${ }^{144}$

Given the context of this speech, Norwegian historian Hans Fredrik Dahl has claimed that Quisling used an exaggerated rhetoric in order to impress and make himself more interesting in the eyes of people like Rosenberg. ${ }^{145}$ However, as genre theory suggests, ${ }^{146}$ on the contrary there seems to be a certain aspect of archetypal logic and mythic cogency to Quisling's narration of the coming Ragnarok between Jews and Aryans, since it emplots agencies and events according to the same narrative structure that Lunde already used in 1934, when he spoke of the 'eternal struggle ... between the divine and the demonic, between that which wants a spiritual development and that which wants to dissolve and destroy'.147

\footnotetext{
144 Quisling, For Norges frihet og selvstendighet, 118.

145 Hans Fredrik Dahl, Quisling: En fører for fall (Oslo: Aschehoug, 1992), 213.

146 Smith, Why War? 62.

147 Lunde, Kampen for Norge I, 83.
} 


\section{Conclusion}

This article has shown how the Ns expressed a conception of history that was ultranationalist, idealist, racist and - after 1935 - strongly antisemitic. This conception of history combined a vision of a futural radical upheaval and palingenesis with a myth of an idealised past. As such, the study highlights the value of analysing the NS through the lens of Griffin's theory of fascism as defined by its core myth of palingenetic ultranationalism. As this theory already suggests, the NS were bent on regenerating the social body conceived in organic terms, to create a rooted modernity that would overturn what they saw as forces of dissolution and decadence in contemporary societies: Marxism and class conflict, liberalism and parliamentarism, and - as time went on - Judaism.

As mentioned in the introduction, Dylan Riley has highlighted how the question of whether fascism represented a revolutionary or a counter-revolutionary movement has 'always been the central dividing-line in the literature about it.'148 If you reserve the term 'revolution' exclusively to socialist, egalitarian change in the property relations of society, then a fascist movement like the NS was certainly counter-revolutionary. In addition to Judaism, their main antagonists were Marxism and the Labour Party, and the latter's dream (at the time) of a society without classes were replaced by the NS with a dream of an inegalitarian, hierarchical society simply where class struggle had been transcended by the unifying force of the national community. Yet, if you instead define revolution as a radical sudden upheaval, as a fundamental, structural change in the political system, then the Ns's desire to foster a new post-democratic society can still be considered 'revolutionary' in its own anti-Marxist terms. Imagining themselves as standing on a threshold to a new era and precipitating a rupture in the flow of historical time, its most passionate converts proposed draconian measures in order to build a bridge between a mythic, idealised past and a new modern, historical era embracing technological, scientific and social advances within a revitalised nationalist myth which would restore a sense of belonging to a heroic future which had been reconnected to a heroic past. To paraphrase from Peter L. Berger's investigations of culture and religion as ways of ordering experience, these temporal regimes spun a 'nomic web'149 over the flow of time, thus providing a shelter from the perceived anomie, ambivalence and decadence of modern societies. 150

\footnotetext{
148 Riley, 'Enigmas of Fascism.

149 Esposito, Fascism, Aviation and Mythical Modernity, 118.

150 Berger, The Sacred Canopy, 20-21.
} 
Yet, the temporal orders analysed not only revolved around a cult of an imagined past and an imagined future. They were also characterised by the modern self-reflexivity about being in history, theorised - amongst others - by Anthony Giddens. ${ }^{151}$ Believing that only great things enter into history, the NS thought they could foster a new golden age that people would look back on, with Quisling as a modern St. Olav or Harald Hårfagre. Hence, their ideology had a built-in sense of living out an episode in the national eternity - of living in real time but doing actions that ultimately belonged to the future and contribute to the Norwegian equivalent of what Hitler called 'German immortality'.152 When he stood trial in 1945, charged with murder, embezzlement and high treason, Quisling claimed that he had only sacrificed himself in an attempt at realising a heroic mission on behalf of the Norwegian people:

For me, politics is not a question of party interests, a career trajectory [levebrødspolitikk], or personal ambition and hunger for power. It is self-sacrifice and acts in the service of the historical development for the good of my own people, and for the promotion of the Kingdom of God on earth that Christ came to establish. If my actions have been treacherous - as they have been portrayed - then I wish to God for the sake of Norway that many of the sons of Norway become traitors like I am, only that they are not thrown into prison. ${ }^{153}$

While Quisling thought he would inaugurate a new era and attain immortality by entering into a 'nationalised eternity', ${ }^{154}$ his name has indeed entered into history, but not the way he planned: as a synonym for a collaborator and traitor.

This article has significant methodological implications in two areas. First, it has highlighted the value of the theory of palingenetic ultranationalism to understanding fascist temporality generically and specifically. Generically, because it shows how the Ns's regime of historicity followed the same structure of revolution and eternity, decay and rebirth, as other fascist movements did. ${ }^{155}$ Specifically, because it also shows how the Ns drew heavily on

\footnotetext{
151 Anthony Giddens, The Consequences of Modernity (Cambridge: Polity Press, 1990), 20-21 and 36f.; See also: Zygmunt Bauman, Modernity and Ambivalence (Cambridge: Polity Press, 1991), 5 . der NSDAP), available at https://archive.org/details/1936-Ewige-Wache.

153 Cited in Dahl et al., Den norske nasjonalsosialismen, 209.

154 Griffin, 'Fixing Solutions,' 18.

155 See in particular: Esposito and Reichardt, 'Revolution and Eternity'; Carstocea, 'Breaking the Teeth of Time'; Griffin, 'Fixing Solutions'.
} 
Norwegian national myths built around the image of the Norse period and of the High Middle Ages as a Golden Age in history, with four hundred years of union with Denmark conceived as a period of decline and decay, of interregnum between two eras of greatness. However, the Ns recoded these narratives, and integrated them into their own fascist temporal order.

Second it has shown how historical case studies, combined with an appreciation of the persistence under modernity of archetypal narratives of the unfolding of time in different eras, as well as an understanding of the processes of sense-making provided by the refined forms of discourse analysis offered by cultural sociology, can deepen our understanding of ideology. An approach informed by cultural sociology helps us recognise how the symbolic systems of an ideology provide 'meaning and motivation' in particular historical situations, and how when a modern nation enters a structural crisis primordial, subliminal tropes of human mythopoeia can surface around which new socio-political movements can take shape to act on history. What this article hopefully demonstrates, is how the combination of the theory of palingenetic ultranationalism with the methods of cultural sociology can help illuminate how the cultural codes, myths and narratives underpinning fascist ideologies gave rise to a variety of expressions and adapted to changing historical circumstances, producing a simultaneous sense of continuity and homogeneity, change and heterogeneity, both within and across specific fascist movements. For instance, fascism's regime of historicity, and its internally structured patterns, produced considerable versatility and dynamic flexibility in its response to rapidly changing historical conditions. It was this mutability that could enable the most fervent believers in the revolution being brought about by the NS to accept the integration of Norway into the Greater Germanic Reich. It also allowed fanatical Nazis to embrace the Ns as a different but generically related form of fascism, effortlessly integrating it into their fantasies of a New European Order. 